\title{
A STUDY ON DIRECT CORRECTIVE FEEDBACK IN IMPROVING STUDENTS' WRITING PERFORMANCE AND MOTIVATION AT MTS YP KH SYAMSUDDIN PONOROGO
}

\author{
Novika Agustiningsih \\ Institut Agama Islam Negeri (IAIN) Ponorogo \\ novikaagustiningsih@gmail.com

\section{Fenty Andriani} \\ Institut Agama Islam Negeri (IAIN) Ponorogo \\ fentyandriani@iainponorogo.ac.id
}

\begin{abstract}
This research is aimed to foster students' motivation in improving writing performance by implementing direct corrective feedback. Direct error correction identifies both the error and the target form. Providing corrective feedback is an essential part of language learning because it influences students' learning and achievement. Feedback helps both teachers and students to meet their goals in teaching and learning. Feedback and motivation are two perceptions which control the students' English as foreign language improvement and progress in learning. This research applied a descriptive qualitative research method. Data gathered through observation, interview, questionnaire, and relevant documents. The research was conducted in the seventh $C$ grade of MTs YP KH Syamsuddin Ponorogo. Thirty five students participated in this research by filling out a questionnaire, and interviewed to obtain more information related to their responses to the questionnaire. The finding of this research indicates that the implementation of direct corrective feedback in improving students' writing performance and motivation in writing teaching learning process was divided into two ways: oral and written. There was also such improvement on students' motivation. The students' responses toward the implementation of direct corrective feedback in
\end{abstract}


improving the students' writing performance were positive because it made them feel comfort in the learning process.

Keywords: Direct Corrective Feedback, Writing Performance, Motivation.

\section{A. Introduction}

English is an international language. For Indonesian students, it is considered as a foreign language and very important to be taught in every level of education. Students are obligated to master English for certain extent. This is aimed for preparing them to adjust to today's global notion in which English is used as a means of oral and written communication. Oral communication is transferring of information from sender to receiver by means of verbal and visual aid. Oral communication is more effectives when communication needs a human touch, establishing a direct relationship, maintaining secrets, reaching mutual understanding and avoiding complexities with oral consent. Next to oral communication, written communication is the oldest known form of communication. Any form of communication which is written and documented from the sender to the receiver is known as written communication. Written communication is more effective when the sender wants to convey complex information, written communication serves better than oral communication (R. Prabavathi, 2018, pp. 29-32).

In learning English, learners need to master four skills. Those are listening, speaking, reading, and writing. Listening and reading skills are regarded as receptive skills, while speaking and writing skills are considered to be productive skills (Harmer, 1989, p. 16). Among those four skills, writing is one of the most powerful tools which is used for conveying and demonstrating what students know. It helps the students to communicate effectively in and out of their schools. When children are not taught how to write effectively, significant barriers in education, employment, and other life pursuits may occur (Lancaster, 2013, p. 3). According to Peter Elbow, writing calls on two skills that are so different that they usually conflict with each other: creating and criticising. In other words, writing calls on the ability to create words and ideas out of one's 
self but it also calls on the ability criticize them in order to decide which one to use (Elbow, 1998, p. 7).

Writing is regarded as the most exacting skill for EFL learner to be mastered. The difficulty lies not only on generating and organizing ideas, but also on translating the ideas into readable text. One major theme in pedagogical research on writing is the nature of the composing process and writing (Brown, 2000, p. 335). Writing skill is complex and sometimes difficult to teach, requiring mastery not only of grammatical and rhetorical devices but also of conceptual and judgmental element (Heaton, 2001, p. 135). The teacher becomes important element in teaching writing to make the process of study is interesting. The suitable strategy or technique used by the teachers will make the students interested in writing activity.

There are so many factors influencing the process of teaching writing. In order to make the teaching writing is successful, the teacher should use suitable technique. Writing simple sentence is the basic level of writing skill. Unfortunately, based on the preliminary observation in MTs YP KH Syamsuddin Ponorogo, the ability of MTs students in writing was still far from expectation. Writing simple sentence was a difficult thing for most of students. They had very poor performance in arranging sentences in logical order and fair in forming a good paragraph structure. The reality shows that in composing grammatical and comprehensible sentences, the students faced many difficulties to choose the appropriate words and correct grammatical sentences. It happened because writing performance requires the knowledge of the rule of sentences, good command of vocabulary and the knowledge of mechanics. They were afraid of making mistakes in their writing. Shortly, they were afraid to fail in producing a good piece of English work of writing. They were not confident in their writing but they did not encourage themselves to develop their writing performance. Hence, they had never practiced the skill unless the teacher asked them. Word order, vocabularies even spelling words were three confusing things. For the result, most of students got dissatisfying score. It is the fact that learning a skill is nothing without practice, including writing skill. It means that the students need to practice a lot to have good writing skill 
The skills involved in writing are highly complex ranging from higher level skills of planning and organizing to lower skills of spelling, pronunciation, word choice, and so on. As it is in many educational settings, teaching writing is examination-oriented, with accuracy as the most important criterion of evaluating students. Thus, correctness in writing is highly valued in these settings and main concerned of many L2 writing teachers to help students to produce accurate writings. One of highly debatable attempts done by teachers is providing corrective feedback (CF) (Elham Almasi, 2016, p. 74).

Feedback is an essential part of language learning because it influences students' learning and achievement. Thus, feedback helps both teachers and students to meet their goals in learning and teaching. There are some studies that examined the relative effectiveness of varying feedback types, with the dichotomy between direct and indirect corrective feedback. Direct error correction identifies both the error and the target form (C.G. van Beuningen, 2008). In this research, feedback aimed to foster students' motivation to improve their writing performance. In effect, motivation is important in foreign language learning because it is the crucial force which determines a learner's engagement in task, how energy $\mathrm{s} /$ he concentrates and how long his/her perseverance in learning. Most of teachers and writers in the field of psychology of learning agree that motivation is a prerequisite for success in language learning. Thus, feedback and motivation are two perceptions that control the EFL students' improvement and progress in learning (Leyla, 2016, p. 2).

Based on researchers' preliminary study, many students need teacher's feedback. Feedback can improve students' writing performance; it may cause positive and negative effect for the students and teachers. It can be positive when the students learn the teacher's feedback and never make mistake again. If the students learn the teacher's feedback, it improves their writing performance. On the contrary, if they do not learn the teacher's feedback, it gives negative effect.

Giving corrective feedback is one of the important techniques in helping the student writers improve their writing pieces, it helps the students to improve their writing. If the mistakes are ignored in the early 
stages without given any feedback, it will be more difficult to deal with them later on. Therefore, it should be given because it is helpful for learners. If the teacher corrects the mistakes of the students' writing, it will help the students learn the mistakes on their writing. Learning their teacher's feedback will help the students avoid those mistakes in the future. This is one of the positive effects of the teacher's feedback.

This study is intended to give information dealing with direct corrective feedback in improving students' writing performance and motivation. It revealed two pints. First is the implementation of direct corrective feedback in improving students' writing performance and motivation. Second is the students' responses toward the implementation of direct corrective feedback in improving writing performance.

\section{B. Method}

To conduct this research, the researchers employed qualitative research method. According to Richard and Schmidt, qualitative research is any research that uses procedures that make use of non-numerical data, such as interviews, case studies, or participant observation (Jack C. Richards, 2002, p. 435). There are many different types of qualitative research. In this research, the researcher used descriptive qualitative research. Descriptive qualitative research is concerning with qualitative phenomenon including surveys and fact-finding enquires in which a specific situation is studied (Kothari, 2004, p. 37). This research took one class of seventh grade of MTs YP KH Syamsuddin Ponorogo. The sample was 35 students of 7 C.

The researchers took the data from observation, interview, questionnaire and documentation. Observation refers to data gathering which involves the use of not only visual sense, but also all the senses necessary to get valid and reliable data (Latief, 2013, p. 77). According to Monette et al. in Ranjit Kumar, an interview involves an interviewer readings question to respondents and recording their answer (Kumar, 2011, pp. 137-138). A questionnaire is an instrument in which respondents provide written response to questions or mark items that indicates their response (Essa Adhabi, 2017, p. 89). A valuable source of information in 
qualitative research can be documents. During the process of research, the investigator may collect qualitative documents. These may be public documents (e.g., newspaper, minutes of meetings, official reports) or private documents (e.g., personal journals and diaries, letters, e-mails) (Creswell, 2009, p. 181).

To analyse the data, the researchers used data analysis technique proposed by Miles and Huberman. The steps were data reduction, data display, and conclusion drawing. Data reduction is a form of analysis that sharpens, sorts, focuses, discards, and organizes data in such a way that "final" conclusions can be drawn and verified. Data display is an organized, compressed assembly of information that permits conclusion drawing and action. Displays helps us to understand what is happening and to do something either analyse further or action based on that understanding. Conclusion drawing is the analysis which provided the information needed to be focused on the subsequent data display (Huberman, 1994, pp. 10-11).

To check the validity of the study, the researchers used data triangulation. Creswell stated that validity is one of the strengths of qualitative research and it is based on determining whether the findings are accurate from the standpoint of the researcher, the participant, or the readers of an account (Creswell, 2009, p. 191). In this study, the researchers used data triangulation. Data triangulation is the analysis and use of data from three or more sources obtained by different methods (Denzin, 1978, p. 14).

\section{The Implementation of Direct Corrective Feedback in Improving Students' Writing Performance and Motivation}

For Indonesian students, English is considered as a foreign language and very important to be taught in every level of education. In learning English, learners need to master four skills. Those are listening, speaking, reading, and writing. Listening and reading skills are regarded as receptive skills, while speaking and writing skills are considered to be productive skills (Harmer, 1989, p. 16). Among those four skills, writing is 
one of the most powerful tools which is used for conveying and demonstrating what students know.

Writing calls on two skills that are so different that they usually conflict with each other: creating and criticising. In other words, writing calls on the ability to create words and ideas out of yourself, but it also calls on the ability criticize them in order to decide which one to use (Elbow, 1998, p. 7). In teaching writing process, students would take some risks and made some mistakes, so that the teacher needed to provide feedback. Feedback is an information provided by an agent with respect to one's rendition or understanding (John Hattie, 2007, p. 81). A further detailed definition of feedback was given by $\mathrm{Ur}$ that feedback is information that is given to the learner about his/her performance (Ur, 1996, p. 242).

Based on researchers' observation and interview, when the teacher gave writing assignment to describe people, the teacher gave direct corrective feedback. The teacher implemented the direct corrective feedback during the learning process. First, when the students were given exercise. Second, when the students were working on assignment. Last, when the students had finished their writing assignment.

There was also such improvement on students' motivation. Motivation is the extent to which you make choice about (a) goals to pursue and (b) the effort you will devote to that pursuit (Brown, 2000, pp. 72-73).

It was found that the teacher gave direct corrective feedback in two types: oral direct corrective feedback and written direct corrective feedback. Oral feedback is mostly considered to happen between a teacher and students (Hadzic, 2016, pp. 6-7). Oral feedback is usually done during a task. It is sometimes underestimated because it is less formal, but it can be very powerful and effective tool as it can be provided easily in the "teachable moment" and in timely way (NWS Governtment, 2021). Oral feedback made the learning situation more responsive. The students who were afraid of being wrong when answering questions before, became more confident. They started give a positive feedback which was good for them in understanding the lesson and the correct structure on writing. 
In contrast, written feedback tends to be given after task. Written feedback is sometimes considered as optimal because it is slightly different from oral feedback in that it requires written comments and a correction of a different kind. Written feedback involves feedback given to students' written work (Hadzic, 2016, p. 10). Effective written feedback provides students with a record of what they are doing well, what needs improvement and suggested next steps.

Through the implementation of direct corrective feedback, it can be seen that students' motivation was high. The experts believe that the characteristics of motivated students are below:

1. Positive task orientation. The learner is willing to tackle tasks and challenges, and has confidence in his or her success.

2. Ego-involvement. The learner finds it important to succeed in learning in order to maintain and promote his or her own (positive) self-image.

3. Need for achievement. The learner has a need to achieve, to overcome difficulties and succeed in what he or she sets out to do.

4. High aspirations. The learner is ambitious, goes for demanding challenges, high proficiency, top grades.

5. Goal orientation. The learner is very aware of the goals of learning, or of specific learning activities, and directs his or her efforts towards achieving them.

6. Perseverance. The learner consistently invests a high level of effort in learning, and is not discouraged by setbacks or apparent lack of progress.

7. Tolerance of ambiguity. The learner is not disturbed or frustrated by situations involving a temporary lack of understanding or confusion; he or she can live with these patiently, in the confidence that understanding will come later (Ur, 1996, p. 275).

The result of the assignment about providing direct corrective feedback in students' writing performance during on characteristic of motivated students is that there is increase of students' motivation. Most 
of them give their answer about how excited they are when the teacher showed the errors corrected by underlining and correcting the errors. That feedback can improve writing skills for the students. Direct corrective feedback is the solution to reduce the type of confusion. Most of the students confuse about the way to understanding or remembering the feedback they got. Besides, direct corrective feedback helped them to get more information to resolve more complex errors.

\section{Students' Responses toward the Implementation of Direct Corrective Feedback in Improving Students' Writing Performance and Motivation}

According to the indicators of students' responses which were applied in questionnaire, the result of the students' responses toward the implementation of direct corrective feedback in improving students' writing performance at MTs YP KH Syamsuddin Ponorogo can be seen in the following table below.

Table 1

The Results of Questionnaire According to Indicators of Motivation

\begin{tabular}{ccl}
\hline NO & INDICATOR & \multicolumn{1}{c}{ RESULT } \\
\hline 1 & Duration & $\begin{array}{l}\text { The writing process that was conducted by the } \\
\text { teacher is classified into high. The students still } \\
\text { found the difficulties so that the teacher gave the } \\
\text { corrective feedback to correct the students' errors. }\end{array}$ \\
\hline & & $\begin{array}{l}\text { The teacher often gave direct correction feedback } \\
\text { by underlining errors and correcting them which } \\
\text { made the students improve their motivation and } \\
\text { ability to correct their own writing task. }\end{array}$ \\
& & $\begin{array}{l}\text { The students had high persistence to achieve their } \\
\text { goals. It was proven when the students agreed if } \\
\text { their tasks were corrected by teacher and they } \\
\text { would correct their mistakes by themselves based } \\
\text { on the teacher's correction. }\end{array}$ \\
& & Persistence
\end{tabular}




\begin{tabular}{|c|c|c|}
\hline 4 & $\begin{array}{l}\text { Resilience } \\
\text { and ability }\end{array}$ & $\begin{array}{l}\text { The students would correct their errors based on } \\
\text { the teacher's correction. It was proven when } \\
\text { students had such resilience and ability to correct } \\
\text { their own errors. }\end{array}$ \\
\hline 5 & $\begin{array}{l}\text { Devotion and } \\
\text { sacrifice }\end{array}$ & $\begin{array}{l}\text { The students had devotion and sacrifice to correct } \\
\text { their errors based on the teacher's correction. }\end{array}$ \\
\hline 6 & $\begin{array}{l}\text { The steps of } \\
\text { appreciation }\end{array}$ & $\begin{array}{l}\text { The teacher gave errors correction to the students' } \\
\text { task and asked them to correct by themselves. It } \\
\text { indicated that the teacher oriented to the goals. }\end{array}$ \\
\hline 7 & $\begin{array}{l}\text { The levels of } \\
\text { qualification } \\
\text { outcomes }\end{array}$ & $\begin{array}{l}\text { After the direct correction feedback given to the } \\
\text { students, there were students who had no } \\
\text { difficulties. But, there were students who still had } \\
\text { difficulties. }\end{array}$ \\
\hline 8 & $\begin{array}{l}\text { The attitude } \\
\text { directions }\end{array}$ & $\begin{array}{l}\text { The students were motivated to correct their } \\
\text { mistakes after the teacher gave the correction } \\
\text { result to them. Then, the students asked the } \\
\text { explanation to the teacher about their mistakes. }\end{array}$ \\
\hline
\end{tabular}

According to the table above, the writing process that was done by teacher is classified into high. But, the students still found the difficulties then the teacher gave the corrective feedback to correct the students' errors. By giving direct corrective feedback, the students had high persistence to achieve their goals. The students were motivated to correct their mistakes after the teacher gave the correction. Direct corrective feedback enables learners to instantly internalize the correct form as provided by the teacher. It also offers more explicit feedback on hypothesis that may have been made.

Based on the indicator result above, the correlation to the index motivation can be seen in table below. 
Table 2

The Correlation between Indicators Motivation and Index Motivation

\begin{tabular}{ccl}
\hline NO & \multicolumn{1}{c}{ INDEX } & \multicolumn{1}{c}{ MOTIVATIONAL RELATIONSHIP } \\
\hline 1 & Task selection & $\begin{array}{l}\text { The students tried to do their task optimally and } \\
\text { never got frustrated if their tasks were corrected } \\
\text { by the teacher. }\end{array}$ \\
\hline \multirow{2}{*}{ E } & Effort & $\begin{array}{l}\text { The students agreed and were pleased to correct } \\
\text { their own errors according to the teacher's } \\
\text { correction. }\end{array}$ \\
\hline 3 Persistence & $\begin{array}{l}\text { The students were motivated to improve their } \\
\text { tasks after their task were corrected by the teacher. }\end{array}$ \\
\hline \multirow{3}{*}{ Appreciation } & $\begin{array}{l}\text { The teacher gave the positive direct correction } \\
\text { feedback and gave true answer on the error marks } \\
\text { which could support students to do better after } \\
\text { the correction. }\end{array}$ \\
\hline
\end{tabular}

Based on the result of the table above, the direct corrective feedback could give stimulus to improve students' motivation in writing English. Direct corrective feedback offers more explicit feedback on hypothesis that has been made. It also enables the students to internalize the correct form as provided by their teacher.

\section{E. Conclusion}

Referring to the findings, it can be concluded that direct corrective feedback has an important power in teaching and learning process. Direct corrective feedback is justification about reactions to a product, a person performance of a task in the purpose of improvement. In this context, direct corrective feedback is a fundamental element of a process approach to writing. Direct corrective feedback gives a lot of influence to enhance the students' writing performance and motivation. The implementation of direct corrective feedback in improving students' writing performance and motivation in writing teaching learning process was divided into two ways: oral and written. There were also such improvements on students' 
motivation. The students were excited and glad once the teacher provided direct corrective feedback. In other word, the students' responses toward the implementation of direct corrective feedback were positive. It was noted that the students felt happier when they got some positive direct corrective feedbacks. They were not only more careful when working on their tasks but they were also not afraid of asking the teacher when they had difficulties.

\section{BIBLIOGRAPHY}

Brown, H. D. (2000). Teaching by Principles an Interactive Approach to Language Pedagogy. San Francisco: Longman.

C.G. van Beuningen, N. d. (2008). The Effect of Direct and Indirect Corrective Feedback on L2 Learner's Written Accuracy. International Journal of Applied Linguistics, 279-296.

Creswell, J. W. (2009). Research Design: Qualitative, Quantitative and Mix Methods Approach. Los Angeles: Sage Publication.

Denzin, N. (1978). An Introduction to Triangulation. Geneva: UNAIDS.

Elbow, P. (1998). Writing with Power. Oxford: Oxford University Press.

Elham Almasi, A. R. (2016). The Effect of Direct vs. Indirect Corrective Feedback on Iranian EFL Learners' Writing Accuracy. Journal of Applied Linguistics and Language Research, 3(1), 74-85.

Essa Adhabi, C. B. (2017). Literature Review for the Type of Interview in Qualitative Research. International Journal of Education, 9(3), 86-97.

Hadzic, S. (2016). Oral and Written Teacher Feedback in an English as a Foreign Language Classroom in Sweden. Växjö: Linnaeus University.

Harmer, J. (1989). The Practice of English Language. New York: Longman.

Heaton, J. (2001). Writing English Language Test. New York: Longman.

Huberman, M. B. (1994). Qualitative Data Analysis. New Delhi: Sage Publication. 
Jack C. Richards, R. S. (2002). Longman Dictionary of Language Teaching and Applied Linguistics. London: Pearson Education Limited.

John Hattie, H. T. (2007). The Power of Feedback. Journal of Educational Research, 77(1), 81-112.

Kothari, C. (2004). Research and Methodology: Method and Techniques. New Delhi: New Age International.

Kumar, R. (2011). Research Methodology. London: Sage Publication.

Lancaster, K. (2013). Using Graphic Organizer to Teach Writing. Charleston: Eastern Illinois University Press.

Latief, M. A. (2013). Research Methods on Language Learning: An Introduction. Malang: UM Press.

Leyla, A. (2016). The Effectiveness of Corrective Feedback on Motivation to Improve Students Writing Performance. Science Language . Biskra: Biskra University.

NWS Governtment. (2021, January 21). Strong Start Great Teachers. Retrieved from https://education.nsw.gov.au/teaching-andlearning/professional-learning/teacher-quality-andaccreditation/strong-start-great-teachers.

R. Prabavathi, P. N. (2018). Effective Oral and Written Communication. Journal of Applied and Advanced Research, 3(1), 29-32.

Ur, P. (1996). A Course in Language Teaching Practice and Theory . New York: Cambridge University Press. 